\title{
The Role of Competition in the Development of Small Industrial Zones
}

\author{
Kamoliddin Murodillayevich Shodmonqulov \\ PhD Student, Tashkent State Agrarian University, Uzbekistan \\ http://dx.doi.org/10.18415/ijmmu.v8i9.3012
}

\begin{abstract}
This article examines the role and importance of competition in the development of small industrial zones from a scientific and theoretical point of view, in which the important aspects of the development of economic zones through investment are discussed in detail.
\end{abstract}

Keywords: Investment; Industry; Small Industrial Zone; Competition; Efficiency; Economic Growth

\section{Introduction}

In recent years, the country has undergone many reforms, including the development of the economy in this area. Free economic zones and small industrial zones are being established. The purpose of this work is to ensure the well-being of our people. There are, of course, shortcomings and problems in the establishment of small industrial zones, and the necessary steps are being taken to address these problems.

Competition is an integral part of the market mechanism. It can be said to be a force that motivates economic entities to act and thereby mobilizes the economy. As competition is a fierce struggle, it does not spare anyone, it encourages all participants in the economy to be vigilant and work tirelessly to save lives. Firms are producers of goods, while households are consumers. Therefore, their goals are different, so they participate differently in the competition. In a competitive environment, the rule is, "There is prosperity in action". As competition takes place in all sectors of the economy, all economically active people participate individually or as a team.

As far as we know, small industrial zones are one of the key factors in the development of entrepreneurship in the regions of the country. This in itself requires the development of competition in small industrial zones, as competition is one of the most important mechanisms in terms of a market economy. What is the competition we have in this regard? We believe that we must study its essence and the laws of its application. So, competition is a struggle between independent producers (enterprises) to produce goods on favorable terms and sell them at a good price, to strengthen their position in the economy as a whole. Competition is a multifaceted economic phenomenon that represents a complex relationship between all market participants. Competition between suppliers of resources is carried out in order to sell their economic resources (capital, land, labor) at a high price. Competition between producers and suppliers of resources is evident in the context of developed market relations and complete liberalization of the economy. 
In the current pandemic, the negative impact on any economic process is, of course, reflected in small industrial zones. We can see this in the following problems: In the context of combating the crisis caused by the coronavirus pandemic in our country, special attention is paid to supporting sectors of the economy and entrepreneurship.

\section{Literature Review}

In this regard, several decrees and resolutions of the head of state have been adopted. They provide a number of preferences and incentives to stimulate economic growth and investment activity, increase production rates and employment, and support businesses. Deputies of the Legislative Chamber of the Oliy Majlis are in the regions to study and systematically organize the work in this direction. The main purpose of the establishment of small industrial zones in Uzbekistan is to bring industry to rural areas and thereby develop the agricultural sector and further improve the welfare of the population in rural areas, which in turn makes it necessary to implement effective agrarian policy. (Allayarov: 2017; Allayarov: 2011)

It should be noted that the development of small industrial zones and the proper organization of their activities is largely related to attracting investment. We know that one of the important conditions for attracting investment in the development of CSR is the creation of a favorable environment. In this regard, the issue of tax culture and tax discipline, along with the provision of tax benefits, is being studied in terms of ensuring the financial security of the country at a time when financial technologies are developing (Allayarov: 2019; Allayarov: 2020). Increasing the competitiveness of CSRs through the development of production and services in remote areas is also important in ensuring financial and economic security, which requires the implementation of effective fiscal policy (Allayarov: 2020; Allayarov, Sh.PhD.: 2020). As an important element in the development of CSR in the field, it is expedient to widely apply the principles of international entrepreneurship through the study of tax control and tax security. (Allayarov, Sh.PhD.: 2020; G. Shamborovskyi: 2020; L.Shaulska: 2021)

\section{The Main Findings and Results}

Indeed, in today's environment, it is more important than ever to support entrepreneurs in every possible way, to create all the necessary conditions for them to operate effectively. In Fergana region, on the basis of the Presidential Decree "On priority measures to mitigate the negative impact of the coronavirus pandemic and the global crisis on sectors of the economy" dated March 19 this year, 37 thousand 89, and according to the Decree "On additional measures to support the population, sectors of the economy and businesses during the coronavirus pandemic" dated April 3, 22 thousand 553 business entities were provided with benefits and preferences.

Particular attention is paid to the creation of new jobs, the production of import-substituting and export-oriented products through the placement of promising business projects in small industrial zones established on the basis of vacant or inefficiently used production areas. (Allayarov, Sh.PhD.: 2020) That is why the Anti-Crisis Fund aims to increase economic activity and employment in the regions.

400 billion soums have been allocated for the construction, reconstruction and repair of infrastructure facilities in small industrial zones of the country. In particular, 39.2 billion soums will be allocated for small industrial zones in Fergana region, which will be spent on existing small industrial zones and 15 small industrial zones in 11 regions. Today, the customer organization is the only one in the region.

The customer's engineering company is responsible for the efficient use of these funds and the preparation of the necessary project estimates, master plans and cadastral documents of small industrial zones, the tender for the selection of companies to perform the order. 
At the meeting with the leadership and participants of the Directorate of Small Industrial Zones, suggestions were also made on the problems that plague them. In particular, in small industrial zones, as a result of the suspension of taxes and other benefits on January 1 this year, the interest of businesses in small industrial zones has decreased. For entrepreneurs who have the status of a participant of a small industrial zone, implementing an investment project, allow them to pay for electricity and natural gas in installments instead of one hundred percent in advance, and payments for the month consumed suggests not to impose a fine for a period of up to ten days in case of delay. Of course, these issues serve to effectively organize their activities.

During the pandemic, efforts are being made to fully organize the activities of business and manufacturing enterprises in the region, to implement the planned projects. This will serve to ensure the stability and efficiency of our economy.

Competition in the market economy means that those who work well, regardless of who they are, win. In this regard, it encourages the economical use of economic resources, the production of goods and services in large quantities and quality, not only to encourage growth, but also to improve economic relations. It creates the most efficient methods of management in the SIZ, forcing them to find the most favorable economic relations.

With economic growth in the SIZ, the scope of competition is expanding. Competition encourages companies to seek and implement scientific and technological innovations, because in this way they can win the fight. It requires the creation of new goods, improving the quality of existing goods, reducing production and commercial costs. Of course, this happens through the discovery and introduction of new technologies. The condition for not losing in the competition is not to save money for innovation, so they can believe in victory in the context of the significant cost of the introduction of scientific innovations in the costs of firms. Large firms are always engaged in research and development. It is no coincidence that US corporations are spending \$ 200 billion on this work.

When there is competition, SIZs have to offer better and cheaper goods to the market than their competitors. To do this, SIZs create new samples of goods that are acceptable to customers, or buy the right to produce samples of goods created by others, reducing costs. Monopolies often compete not on price but on quality, for which they introduce scientific and technical achievements into production. For example, car companies present super new models of cars at international car shows (exhibitions). When implementing a car model, they implement new technical ideas in the design of the model. This means that competition with quality will become a factor in the development of science and technology.

Another condition for competitiveness in SIZ is to attract to the company skilled workers and specialists who are able to effectively use advanced technology. To do this, companies not only compete in the labor market as buyers, but also spend a lot of money on training and retraining of employees. In this case, the cost of human capital is considered to be the most convenient placement. Nowadays, the primary emphasis on the human factor in competition is widespread, especially in Japan.

In Japan, the company has organized circles to improve the quality of work of employees, which are aimed at the production of competitive goods. There is a strong emphasis on solidarity among the company's employees and avoids social conflicts.

Competition also reveals the activity of SIZs. Every worker in the apartment is looking for a good job, trying not to lose it. A good job is a place where you are provided with a stable job and get a good salary. The struggle for such a place is constant. In order to achieve their goals in this struggle, workers and employees are required to adhere to labor discipline, not to be lazy, to work with initiative, to increase labor productivity and, finally, to ensure the quality of goods. The struggle for jobs leads them to constantly improve their knowledge and professional skills, to take care of their health. Competition leads families to increase the cost of educating their children well. For example, in the Republic of Korea, in order to provide children with the most modern education and good upbringing, well-off families send 
30,000 children a year to study abroad. In short, competition in the labor market increases the quality of labor and thus stimulates economic growth.

In competition, the principle of economic selection, typical of a market economy, applies in the SIZ. Here, if one of the contestants wins, the other loses. For this reason, competition leads to a strict stratification of economic entities. This is manifested first of all in the amount of profit, the amount of capital, the ability to repay the debt, and finally in the difference in wages. As the winners of the competition become stronger economically, the losers weaken, and even become homeless and bankrupt. We know that bankruptcy is the inability to fulfill one's obligations and payments. Bankrupt companies will disappear. There are two conflicting consequences of economic selection. First, the failure of firms that have failed to do their job is to select the most enterprising and hand over the economy to their trustworthy hands; secondly, these forces will intensify and create a tendency to monopolize, resulting in limited free competition. Therefore, the state, with its antitrust measures, promotes the emergence of new firms instead of broken ones, as enterprises are more competitive in many places. Therefore, in order for competition to be effective, it is necessary to ensure a balance between competitors, which will prevent monopolization.

The power of competition is constantly increasing. Where competition takes its rightful place, production develops rapidly and the living standards of members of society are high.

There are 2 types of competition. The first is intra-network and the second is inter-network. Competition accelerates economic growth; scientific and technical achievements in production, rapid introduction of technology; plays an important role in improving the quality of products. The task of placing the resources of competition in the SIZs allows to rationally placing the factors of production in the enterprises, regions and regions where they are most effective. The innovative task of competition is the introduction of various innovations based on the achievements of scientific and technological development and the development of market economy entities. The task of adaptation of competition is aimed at the rational adaptation of enterprises to the conditions of the internal and external environment, which means the transition from self-sufficiency and economic survival to the expansion of economic activities.

The function of the distribution of competition has a direct and indirect effect on the distribution of the total volume of goods produced among consumers. Finally, the task of controlling competition is to prevent some market participants from establishing monopolistic dominance over other participants.

In order to have a fuller understanding of the content of competition, it is necessary to consider its main forms and features. The economic literature distinguishes four forms of competition within an industry: free competition, monopolistic competition, monopoly and oligopoly.

Competition also occurs among consumers, and the focus is on buying goods at affordable and affordable prices, i.e., the buyer tries to have more profitability for every penny spent, struggling to buy cheap and quality goods faster. . In the competition, there is a struggle between producers to make more profit on the costs incurred, and as a result of this profit, the areas of sale of goods, i.e., favorable markets, cheap raw materials, energy and cheap labor resources. Competition is based on the separation and independence of producers as property owners, and conflicts of interest. Because every property owner has their own interests, and they strive to achieve those interests. The property owner's activities in the production of goods and in all other areas will be subject to this interest. Another condition for the existence of competition is the existence of commodity-money relations, a certainly developed market system. Therefore, the main area of competition is the market.

Further improvement of the system of coordination and management of small industrial zones, qualitative improvement of working conditions for their participants and assistance in selling products, intensification of investment attraction, first of all on production of imported products based on unused, inactive production areas In order to accelerate the introduction of modern industries, to ensure the creation of new stable jobs on this basis and increase incomes: 
On June 20, 2019, the President of the Republic of Uzbekistan Shavkat Mirziyoev adopted a resolution "On measures to further improve the coordination and management of small industrial zones". We can see that the implementation of the Resolution of the President of the Republic of Uzbekistan on measures to further improve the coordination and management of small industrial zones has been fully implemented in the following indicators:

As part of the ongoing measures to support the development of new competitive industries and small businesses, 150 small industrial zones have been established, with a total of more than 1.7 trillion soums annually. There are 1,691 small enterprises with a production capacity of value-added products and more than 27,000 jobs have been created. One of the most significant steps being taken today to further improve the coordination and management of small industrial zones is to facilitate the exchange of information in these activities. In other words, the e-cooperation portal has been launched to facilitate the operation of small industrial zones. The portal has the following advantages:

- free posting of information about manufactured products;

- convenient trading platform for work at any time;

- quick and easy access to the local market for new manufacturers;

- participation of industrial enterprises in the national trade;

- sale and purchase of products without intermediaries;

- and access to a mobile app.

The introduction of new technologies, the rapid development of demand-driven products, the availability of a skilled workforce and the use of modern marketing services will become a prerequisite for winning the competition. Monopoly is anti-competitive because it provides the producer with sole control and does not create conditions for competition. Competition is divided into fair and impartial in terms of the choice of the path of struggle. Fair competition is based on market rules, accepted in the struggle in the market, in ways that are acceptable to all. Prohibited and condemned methods of competition include criminal methods such as fraud, deception, disobedience, deception, economic espionage, subversion, and even physical violence. The market economy actually only recognizes fair competition. Competition keeps the economy healthy. Antitrust laws passed by the state play an important role in the use and control of competition in the public interest.

The state's competition policy is aimed at ensuring its enlightened, cultural appearance and rules. Such a policy will help to improve production, efficient distribution of products, technical and economic development, and protect the interests of consumers.

During the transition to a market economy in Uzbekistan, the government has paid special attention to creating a competitive environment in the economy. As in all developed countries of the world, Uzbekistan pursues a state policy of competition. To this end, on March 15, 1996, the Committee on De-monopolization and Development of Competition was established under the Ministry of Finance. It was later transformed into an independent state committee. In order to create a competitive environment in Uzbekistan, the method of price competition was chosen and prices were set freely.

The Law "On the Restriction of Monopolistic Activities" (August 3, 1992) prohibits the monopolization of prices, the creation of a deliberate shortage in the market, and the use of rigid competition. The Law on Consumer Protection (April 26, 1996) also pays special attention to the creation of a mechanism to prevent unfair competition. The Law "On Competition" (December 27, 1996) also provides the legal conditions for a healthy competitive environment. 


\section{Conclusion}

Competition is a rational means of regulating key economic processes, distributing material goods, and satisfying the interests of consumers. Competition is not self-regulating. Therefore, in order for the market to function rationally, it is necessary to regulate the existing relations in a competitive environment by a special law. Competition is necessary for everyone, everywhere.

We know that without competition, there will be no aspiration, no development. Competition is the struggle of economic participants to fully express their interests, that is, to earn a good income, to strengthen their position, to show their abilities.

Usually in developed countries there is no requirement to sell goods in a certain order and form. It is up to the consumer to decide what, where, from whom and at what price to buy, depending on their desire and ability to pay. As competition grows, people's living standards will improve, and the elimination of competition will lead to an economic crisis and a decline in people's living standards. Only through competition can low-cost, high-quality goods be produced and sold.

We should now focus on lowering prices and improving quality by ensuring healthy competition between small industrial zones, rather than setting prices. It is necessary to study international experience and pave the way for small industrial zones to monopolize areas where competition can be introduced, thereby creating a competitive environment. In our opinion, it is necessary to develop a promising strategy for the formation of a competitive environment in small industrial zones.

To sum up, the main criterion should be the implementation of reforms based on the rule of law and ensuring transparency and fairness in this regard. A lot of work is being done in Uzbekistan in this direction, especially through the effectiveness of judicial reform, which contributes to the development of entrepreneurship at all levels, which in turn contributes to the development of small industrial zones. Therefore, we believe that the widespread application of the above ideas in practice will serve to further develop small industrial zones in our country and alleviate the existing problems.

\section{References}

Allayarov Sh.A. Features and ways to improve the current model of agricultural policy of Uzbekistan//INTERNATIONAL JOURNAL OF RESEARCH IN SOCIAL SCIENCES, (ISSN:22492496), Impact Factor (IJRSS) 7.081 for 2016// April 2017. P 212-223.

Allayarov Sh.A. Modernization of the agricultural sector of Uzbekistan: problems and solutions. Financial bulletin - finance, taxes, insurance, accounting. Index 45427. (Russia) 2011. No. 12. - pp. 17-24. http://www.finance-journal.ru/index.php (Аллаяров Ш.А. Модернизация аграрного сектора Узбекистана: проблемы и решения// Финансовий вестник-финансы, налоги, страхование,бухгалтерский учет. Индекс 45427. (Россия) 2011.- №12.- с. 17-24. http://www.finance-journal.ru/index.php)

Allayarov, Sh. (2019) "ON THE INTERDEPENDENCE OF THE CONCEPTS OF “TAX CULTURE" AND "TAX DISCIPLINE"// International Finance and Accounting: Vol. 2019: Iss. 6, Article 14. Available at: https://uzjournals.edu.uz/interfinance/vol2019/iss6/14

Allayarov, Sh. PhD; Mirzamakhmudov, M.; and Mirzamakhmudova, M. (2020) "ANALYSIS OF REGULATORY SANDBOX IN THE NETHERLANDS THAT PROMOTE DEVELOPMENT OF INNOVATIVE FINTECH STARTUPS"// International Finance and Accounting: Vol. 2020: Iss. 3, Article 34. Available at: https://uzjournals.edu.uz/interfinance/vol2020/iss3/34

Allayarov, Sh., Allayarov S., Yuldasheva U., Madjidov N. (2020) Assessment of the effectiveness of the results of the fiscal policy of the republic of Uzbekistan// International Journal of Advanced Science and Technology Vol. 29, No. 7, (2020), pp. 7920-7926. 
Allayarov, Sh., Nabiev E., Allayarov S., Amanullaeva Yu. (2020) Ways To Improve The Tax Mechanism To Ensure The Financial Security Of The Country//International Journal of Advanced Science and Technology. Vol. 29, No. 7, (2020), pp. 7849-7855.

Allayarov, Sh.PhD. (2020) Faktor investigation of tax discipline for financial security// ACADEMICA: An International Multidisciplinary Research Journal. https://saarj.com.ISSN:2249-7137, Vol. 10, Issue 11, November 2020, Impact Factor: SJIF 2020=7.13, pp 2343-2348.

Allayarov, Sh.PhD. (2020) Combination of fiscal and stimulating functions of the tax system to ensure financial and economic security//AMERICAN JOURNAL OF ECONOMICS AND BUSINESS MANAGEMENT ISSN:2576-5973, Vol. 3, No.1, Jan-Feb 2020, pp 64-69.

Allayarov, Sh.PhD. (2020) Strengthening tax discipline in the tax security system: features and current problems//South Asian Journal of Marketing \& Management Research (SAJMMR). https://saarj.com. ISSN: 2249-877X, Vol. 10, Issue 11, November 2020, Impact Factor: SJIF 2020=7.11, pp. 124-128.

Allayarov, Sh.PhD. (2020) The improvement of tax control in order to strengthen tax discipline in the republic of Uzbekistan// TRANS Asian Journal of Marketing \& Management Research (TAJMMR). https://tarj.in ISSN: 2279-0667, Vol 9, Issue 11, November 2020, Impact Factor: SJIF 2020=7.209, pp. $57-62$.

G. Shamborovskyi, M.Shelukhin, Allayarov Sh, Y.Khaustova, S. Breus. (2020) Efficiency of functioning and development of exhibition activity in international entrepreneurship// Academy of Entrepreneurship Journal (Print ISSN: 1087-9595; Online ISSN: 1528-2686) Volume 26, Special Issue 4, 2020. pp. 1-7.

Hamroyev H. R. (2006) A free economic zone is a school that teaches world experience. Problems of Education and Employment (materials of the international scientific and practical conference). Samarkand. pp. 441-445 (Hamroyev H.R. Erkin iqtisodiy zona - jahon tajribasini o'rgatuvchi maktab sifatida.//“Проблемы образования и занятости» (материалы международной научнопрактической конференции). - Samarqand: 2006. -С. -441-445.)

Karimqulov J.I. (2019) Directions for the development of foreign investment in free economic zones 08.00.07 - Author's abstract of the dissertation "Doctor of Economics (DSs)", "Finance, money circulation and credit". Tashkent.

L.Shaulska, S.Kovalenko, Allayarov Sh, O.Sydorenko, A.Sukhanova (2021). Strategic enterprise competitiveness management under global challenges // Academy of Strategic Management Journal, JEL Classifications: M5, Q2/ Volume 20, Issue 4, 2021

On additional measures to encourage the introduction of innovative projects and technologies in production. Resolution by President of the Republic of Uzbekistan No. PD-916 of July 15, 2008.

Regulation of the Cabinet of Ministers of the Republic of Uzbekistan dated December 31, 2014 "On the procedure for the establishment of small industrial zones and the organization of their activities".

Resolution of the President of the Republic of Uzbekistan Shavkat Mirziyoev No. PP-4363 "On measures to further improve the coordination and management of small industrial zones". 21.06.2019.

\section{Copyrights}

Copyright for this article is retained by the author(s), with first publication rights granted to the journal.

This is an open-access article distributed under the terms and conditions of the Creative Commons Attribution license (http://creativecommons.org/licenses/by/4.0/). 